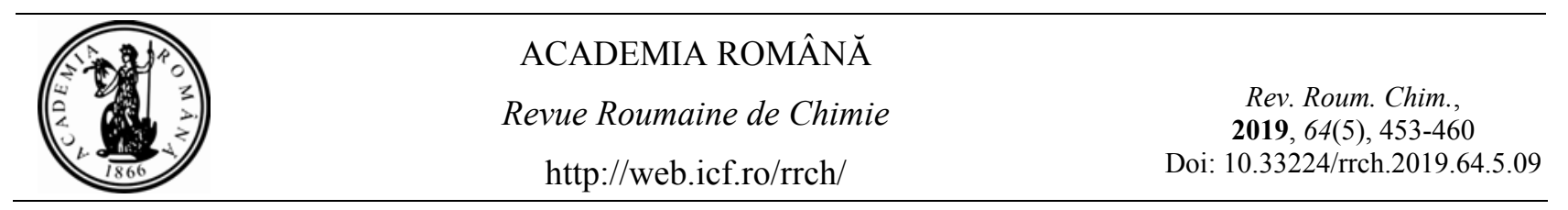

\title{
TG/DTG ANALYSIS OF AN ECO-FRIENDLY SCOURED FABRIC
}

\author{
Dorina CHAMBRE, ${ }^{a}$ Mihaela DOCHIA ${ }^{\mathrm{b}, *}$ and Simona GAVRILAŞa \\ ${ }^{a}$ AUREL VLAICU University, Faculty of Food Engineering, Tourism and Environmental Protection, Elena Drăgoi 2-4, \\ 310330 Arad, Roumania \\ ${ }^{\mathrm{b}}$ AUREL VLAICU University, Research Development Innovation in Natural and Technical Sciences Institute, Elena Drăgoi 2-4, \\ 310330 Arad, Roumania
}

The TG/DTG analysis of the raw cotton-flax fabric ( $40 \%$ flax$60 \%$ cotton), bioscoured samples with/without ultrasonication (in the presence of different enzyme concentration and action time) and of the alkaline treated sample has been achieved aiming to study the influence of the experimental conditions on the pectin elimination and quantifying the efficiency of the eco-friendly process. TG/DTG results were correlated with FT-IR data. Even at a short action enzyme time the results demonstrate the efficacy of the ultrasonication in the ecofriendly scouring process, which becomes more pronounced as the enzyme concentration and action time increases.

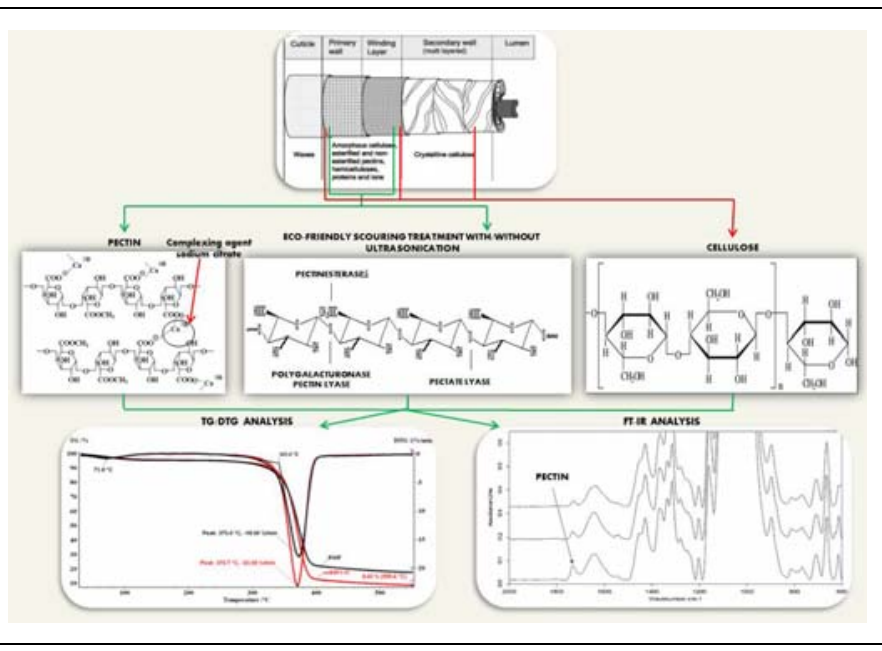

\section{INTRODUCTION}

Cotton - a cellulosic fibre, and flax - a lignocellulosic fibre, are important raw materials for the textile industry due to their qualities like softness, comfortability, durability, freshness and biodegradability. ${ }^{1-3}$ Both fibres have a multilayered structure mainly consisting from cellulose (cotton $86-96 \%$, flax $-70-75 \%$ ), but also a number of other non-cellulosic components, considered impurities such as pectin (cotton - 0.7-1.2\%, flax 10-15\%), waxes, hemicelluloses (flax - 15\%), proteins, organic acids, minerals / ashes, etc. that are present in the cuticle and in the primary wall. ${ }^{4-7}$ In the present, the textile industry uses these natural fibres both individually and in mixture to obtain a wide range of fabrics. The non-cellulosic content is responsible for the non-wetting behaviour of fibres, causing a number of technical problems during the dyeing and other finishing processes. ${ }^{2,8,9}$ For obtaining high quality cellulosic/ lignocellulosic fabrics with sufficient whiteness and wettability, it is necessary to remove the noncellulosic compounds, especially pectin. ${ }^{3}$ Pectin is present in fibres as methyl ester or calcium salts form of the (1-4) poly-D-galacturonic acid and builds a network with its structure that plays a bonding role between cuticle and primary wall. ${ }^{10}$ The other impurities are dispersed through the backbone and side chains of pectin. ${ }^{7,11}$ The removal of the non-cellulosic constituents from cellulosic/lignocellulosic fibres is called the scouring

\footnotetext{
*Corresponding author: dochiamihaela@yahoo.com
} 
treatment. ${ }^{2,3}$ This is performed in an alkaline way which uses a large quantity of chemicals $(\mathrm{NaOH})$, various chemicals auxiliaries and water at high temperature for pectin degradation by hydrolysis or in biochemically way (bioscouring) by treating the textile materials with an enzyme like pectinases or with a mixture of enzymes in the presence of an polydentate ligands (EDTA) as complexing agent. ${ }^{12-18}$ The trend in the textile industry was to replace the alkaline scouring, which is a pollutant method, with eco-friendly scouring treatments that use enzymes. Moreover, lately, the tendency is to replace EDTA, known to be toxic with a biodegradable complexing agent like sodium citrate. $^{2,7,16,19}$ In addition, the acceleration of mass transfer during enzyme treatment can be done by ultrasonication. ${ }^{3}$

Although the thermogravimetrical analysis is a widely used technique to study the thermal degradation of cellulosic materials ${ }^{20-25}$ so far, it has been used less as an alternative method to common ones (whiteness degree, wettability, FT-IR, etc.) to evaluate the efficiency of the bioscouring treatment. The remanent pectin from the material can be considered an indicator for process efficiency and the study of its influence on the thermal decomposition of cellulose becomes necessary.

Continuing the previous work, ${ }^{2,12,16,18}$ in this paper we present the results obtained from TG/DTG analysis in order to study the influence of the experimental conditions (ultrasonication, concentrations and action time of enzyme) on the pectin elimination and to evaluate the efficiency of the bioscouring process of a cotton-flax fabric ( $40 \%$ flax$60 \%$ cotton). Efficacy of pectin elimination was estimated from the mass-loss values $\left(\% \Delta \mathrm{m}_{2}\right)$ recorded for the main decomposition step of cellulose $\left(260-400^{\circ} \mathrm{C}\right)$ and from the \% residual-mass (at $550^{\circ} \mathrm{C}$ ) values. Also, the FT-IR spectra of the samples were recorded and the effect of the experimental conditions on scouring efficiency was estimated through noticing the changes on the specific bands of the residual pectin located at $2916 \mathrm{~cm}^{-1}, 2852 \mathrm{~cm}^{-1}$ and $1731 \mathrm{~cm}^{-1}$.

\section{EXPERIMENTAL}

For FT-IR and TG/DTG the following samples were analysed: raw woven cotton-flax fabric denoted as RWF sample $(60 \%$ cotton $+40 \%$ flax untreated woven blended fabric without sizing agent, preliminary washed and conditioned); alkaline treated cotton - flax fabric denoted as ATF sample (raw sample treated at $95{ }^{\circ} \mathrm{C}$ with 10 g. $\mathrm{L}^{-1}$ sodium hydroxide for 55 minutes); bioscoured cotton - flax fabric samples with or without ultrasonication denoted as
usBSFx-y or BSFx-y, respectively (were $\mathbf{x}$ is the concentration of enzyme, \% over weight fiber - o.w.f, and $\mathbf{y}$ - minutes of the enzyme action time) - usBSF1-35, usBSF2-15, usBSF2-35, usBSF2-55, usBSF3-35 and BSF1-35, BSF2-15, BSF2-35, BSF2-55, BSF3-35. The preparation of the samples was done according to the methods presented in a previous work. ${ }^{26}$

The FT-IR and TG/DTG experiments were performed on samples taken from different areas of conditioned cotton-flax fabric (up to $105^{\circ} \mathrm{C}$ on Sartorius MA 100 system), chopped and mechanical homogenized. The FT-IR spectra of all investigated samples were acquired using the Bruker Vertex 70 spectrophotometer equipped with the ATR cell, on the 600$3000 \mathrm{~cm}^{-1}$ wavelength range with a resolution of $4 \mathrm{~cm}^{-1}$ and 100 scans. The spectra were processed using the OPUS software. The recorded FT-IR spectra were normalized and baseline corrected. The TG/DTG experiments for the investigated cotton fabric samples were performed on a STA 409C Luxx system, produced by Netzsch-Germany. The experiments were conducted on $30-550^{\circ} \mathrm{C}$ temperature range, at $10 \mathrm{~K}^{-m^{-1}}$ heating rates, using platinum crucibles in dynamic nitrogen atmosphere $\left(50 \mathrm{~mL} \cdot \mathrm{min}^{-1}\right)$. The samples mass was $\sim 10 \mathrm{mg}$. The curves were processed using the Netzsch Proteus software. All experiments were done in triplicate.

\section{RESULTS AND DISCUSSION}

\section{FT-IR analysis}

The FT-IR attenuated total reflectance (ATR) spectroscopy has proven to be useful in the evaluation of the bioscouring process of the cellulosic/lignocellulosic fabrics because can highlight changes in the main non-cellulosic compounds by characterizing the carboxyl acids and esters bands that are present in pectin which do not exist in the cellulose structure. ${ }^{5,7,27-30}$ In the FT-IR spectra of the investigated samples shown in Fig.1 the band at $3000 \mathrm{~cm}^{-1}-3600 \mathrm{~cm}^{-1}$ can be assign to the free $\mathrm{OH}$ stretching vibration and to the intra- and intermolecular hydrogen bond related to chemical structure of cellulose., ${ }^{3,5,928}$ The two bands located at $2917 \mathrm{~cm}^{-1}$ and $2851 \mathrm{~cm}^{-1}$, are attributed to the stretching vibration of $-\mathrm{CH}_{2}$ - and - $\mathrm{CH}$ - groups from pectin, hemicellulose and waxes. ${ }^{5,28,29}$ The bands at around $1731 \mathrm{~cm}^{-1}$ and $1642 \mathrm{~cm}^{-1}$ are characteristic for pectin and can be assigned to the $\mathrm{COOH}$ and $\mathrm{COOCH}_{3}$ groups of polygalacturonic acid and to symmetrical/ asymmetrical oscillations of ionized carboxyl groups - $\mathrm{COO}^{(-)}{ }^{5,15,19,28}$ It should be noted that the characterization of the carboxyl ion band around $1550 \mathrm{~cm}^{-1}-1650 \mathrm{~cm}^{-1}$ by FT-IR is quite difficult because the $\mathrm{OH}$ bending of absorbed water $\left(1642 \mathrm{~cm}^{-1}\right)$ was also observed in this regions ${ }^{5,30} \mathrm{so}$, many authors recommend the investigation of the band from $1731 \mathrm{~cm}^{-1} .5,15,30$ In the $600 \mathrm{~cm}^{-1}-1500 \mathrm{~cm}^{-1}$ fingerprint area, specific and common bands appear, assigned to cellulose. ${ }^{19,27,28}$ 


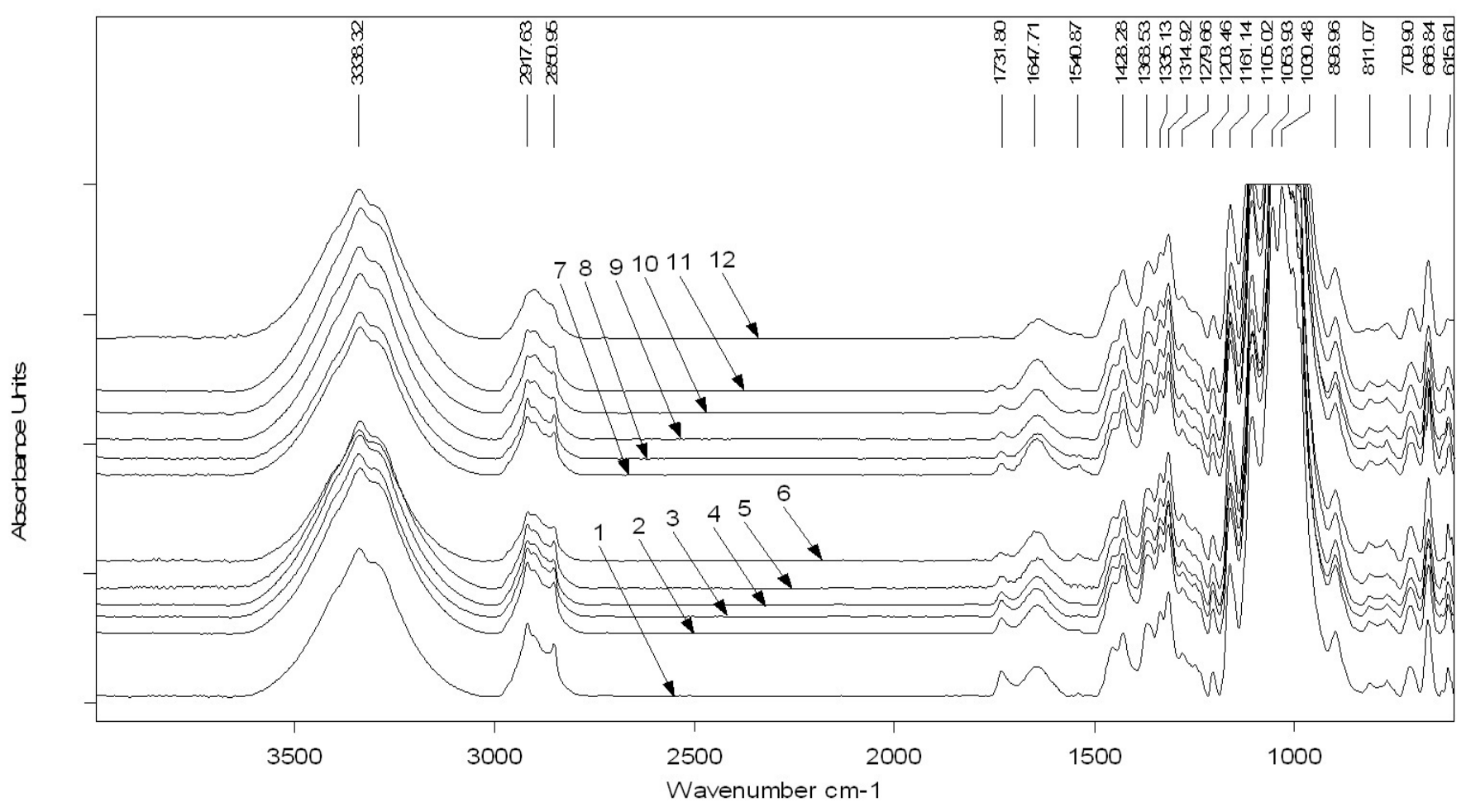

Fig. 1 - FTIR spectra of: 1-RWF; 2-BSF2-15; 3-BSF1-35; 4-BSF2-35; 5-BSF3-35; 6-BSF2-55; 7-usBSF2-15; 8-usBSF1-35; 9- usBSF2-35; 10-usBSF3-35; 11-usBSF2-55; 12- ATF.

Table 1

The relative absorbance values $\left(A_{1731}\right)$ of the pectin $\mathrm{COOH}$ and $\mathrm{COOCH}_{3}$ groups for the cotton-flax fabric samples

\begin{tabular}{c|c}
\hline Samples & $\boldsymbol{A}_{\mathbf{1 7 3 1} \text { a.u. }}$ \\
\hline RWF & 0.465 \\
BSF2-15/ usBSF2-15 & $0.412 / 0.229$ \\
BSF1-35/usBSF1-35 & $0.372 / 0.211$ \\
BSF2-35/ usBSF2-35 & $0.271 / 0.120$ \\
BSF3-35/ usBSF3-35 & $0.197 / 0.097$ \\
ATF & n.d. \\
BSF2-55/ usBSF2-55 & $0.164 / 0.086$ \\
\hline
\end{tabular}

The recorded FT-IR spectra show difference between the pectin bands corresponding to RWF and to the treated bioscoured and alkaline fabric samples. The intensity of those two bands located at $2917 \mathrm{~cm}^{-1}$ and $2851 \mathrm{~cm}^{-1}$ decrease with the increasing of the concentration and action time of enzyme even in the absence of ultrasonication and this behaviour becomes more evident for ultrasonicated samples, respectively for the ATF sample. Regarding the band at $1731 \mathrm{~cm}^{-1}$, the data reported in Table 1 show the decrease of the relative absorbance values $\left(A_{1731} /\right.$ a.u. $)$, as the pectin is eliminated from the samples. Similar behaviour was reported in the literature by Wang Q. et al. for the characterization of bioscoured cotton fabrics using FT-IR ATR spectroscopy. ${ }^{5}$
With the increase of the concentration and enzyme action time the $A_{1731}$ values of BSFx-y decreases relative to RWF. For usBSFx-y samples the obtained results are considerably lower even at a short time (15 min.) of enzymes action. This behaviour demonstrates the efficacy of the ultrasonication in the bioscouring process which, according with reported data, ${ }^{3,9}$ improve the diffusion, mass and heat transfer. However, the vibration peak at $1731 \mathrm{~cm}^{-1}$ attributed to the $\mathrm{C}=\mathrm{O}$ stretching of methyl ester and carboxylic acid in pectin does not completely disappear for bioscoured samples suggesting that for the cottonflax fabric the total elimination of the pectin is quite difficult since flax contains pectin not only on the surface of the fibres but also between the elementary fibres. For ATF sample the FT-IR 
spectrum suggests the total removal of pectin and hemicelluloses by alkalisation. Also, from Fig. 1 it was noticed that, with the exception of ATF and usBSF 2-55 for the others bioscoured samples, the bands located at $600 \mathrm{~cm}^{-1}-1500 \mathrm{~cm}^{-1}$ (cellulose fingerprint area) don't present important changes, meaning that the enzyme treatment did not considerably affect the cellulose structure and crystallinity. This behaviour can be an advantage of eco-friendly scouring treatment compared to alkaline treatment which due to its aggressivity, especially at high $\mathrm{NaOH}$ concentrations and high temperatures, it can affect the cellulose structure with negative consequences on fabrics quality. ${ }^{31,32}$ For the ATF and usBSF2-55 samples an increase in the intensity of the $896 \mathrm{~cm}^{-1}$ band ("amorphous" absorption band), assigned to -C-O-C- stretching of $\beta$-(1-4)-glycosidic linkages and a decrease of the band at $1428 \mathrm{~cm}^{-1}$ ("crystallinity band"), assigned to a symmetric $-\mathrm{CH}_{2}$ - bending vibration, ${ }^{31}$ were noticed compared to the values obtained for the RWF $\left(A_{896, \mathrm{RWF}}=0.421, A_{1428, \mathrm{RWF}}=0.362\right.$, $A_{896 \text {,usBSF2-55 }}=0.563, A_{1428,}$ usBSF2-55 $=0.302$, $A_{896, \mathrm{ATF}}=0.679, A_{1428, \mathrm{ATF}}=0.209$ u.a.). These results suggest a destruction of the crystalline cellulose structure in the presence of alkaline conditions or for a long sonication time. The bands at $1540 \mathrm{~cm}^{-1}$ and $811 \mathrm{~cm}^{-1}$ are specific for lignin from flax component and were diminished in the ATF case.

\section{Thermal analysis}

The TG/DTG curves recorded in nitrogen atmosphere on $30-550^{\circ} \mathrm{C}$ for RWF, ATF, BSFx-y and usBSFx-y are shown in Fig. 2, Fig. 3 and Fig. 4.

The analysis of the TG/DTG curves shows that the non-isothermal degradation of the investigated cottonflax fabric samples occurs through two processes accompanied by mass-losses $(\% \Delta \mathrm{m})$. The first process, $\left(\% \Delta \mathrm{m}_{1}\right)$, recorded between $60-120^{\circ} \mathrm{C}$ with the peak temperature on DTG curve at $\mathrm{T}_{\mathrm{DTG}} \sim 72^{\circ} \mathrm{C}$ is due to the humidity elimination from textile samples. From $120^{\circ} \mathrm{C}$ to $260^{\circ} \mathrm{C}$ the samples were quite stable. The second decomposition process corresponds to the main mass-loss stage, $\left(\% \Delta \mathrm{m}_{2}\right)$, and was recorded in the $260-400^{\circ} \mathrm{C}$ temperature range.

In all investigated fabric samples a \% residualmass at $550^{\circ} \mathrm{C}$ was noticed due to the formation of the carbonaceous residues from polymeric compounds degradation and to the ashes, naturally present in cotton and flax fibres.
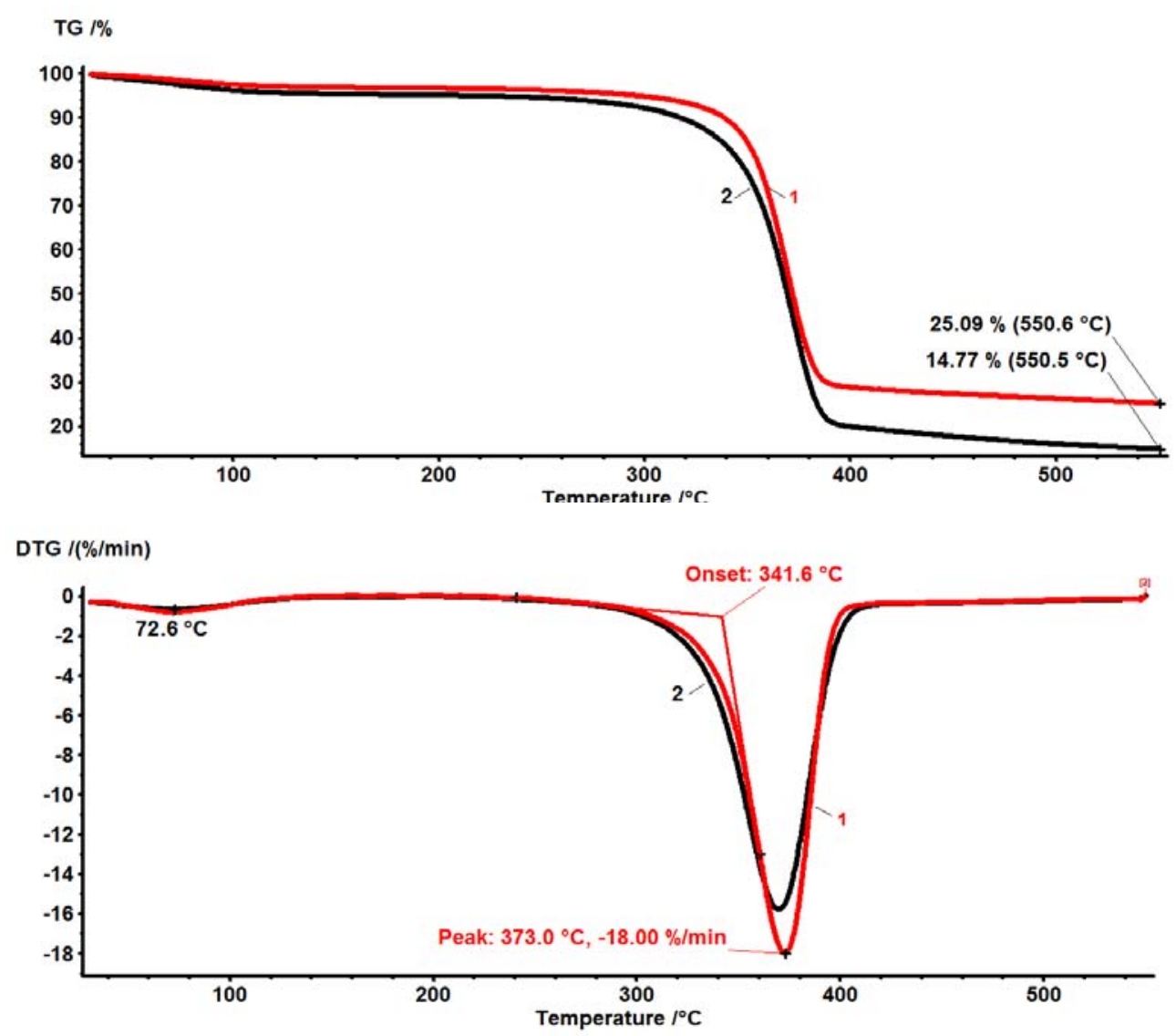

Fig. 2 - TG/DTG curves of 1-RWF and 2- ATF samples. 

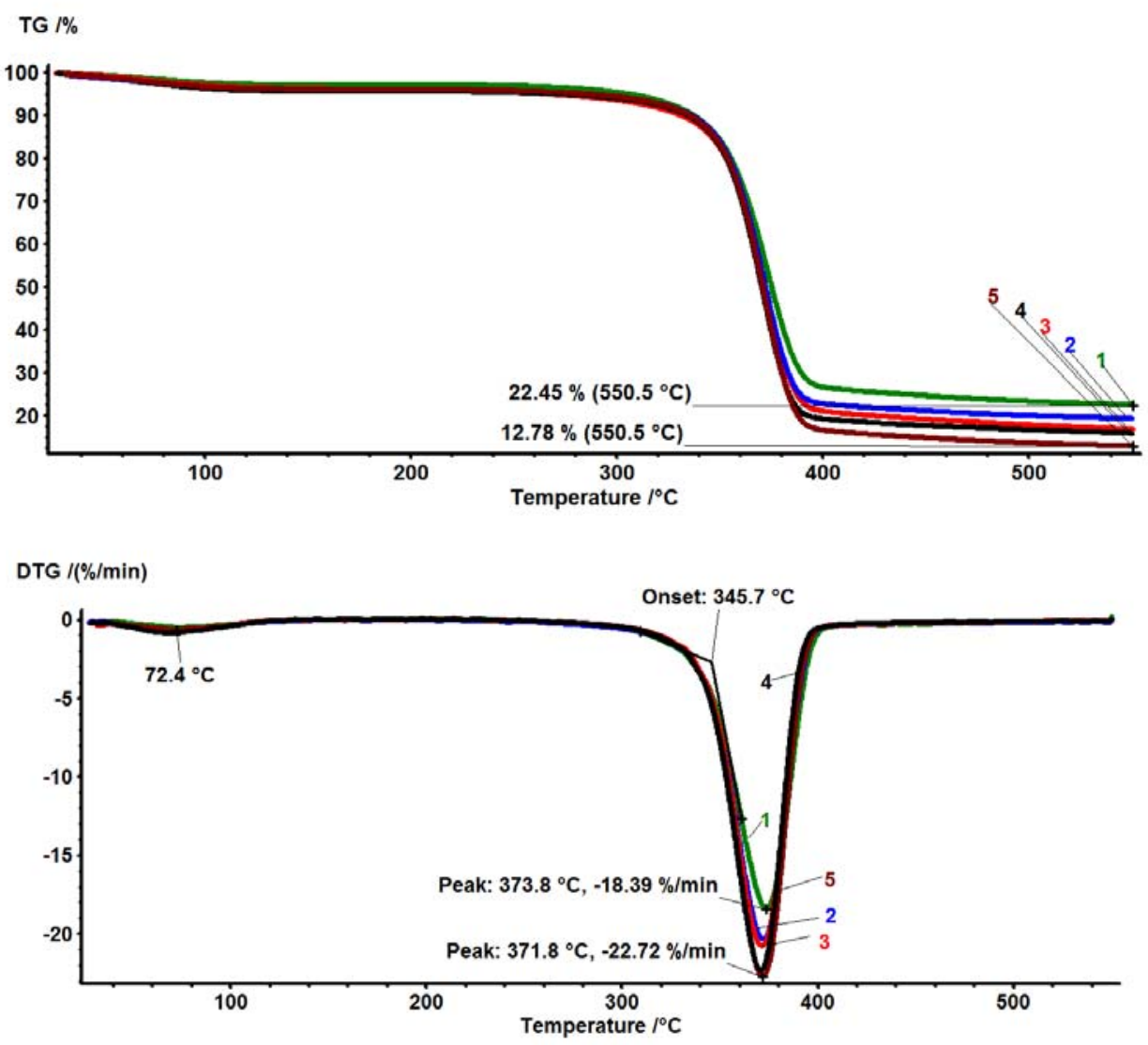

Fig. 3 - TG/DTG curves of: 1-BSF2-15, 2-BSF1-35, 3-BSF2-35, 4-BSF3-35, 5-BSF2-55 samples.

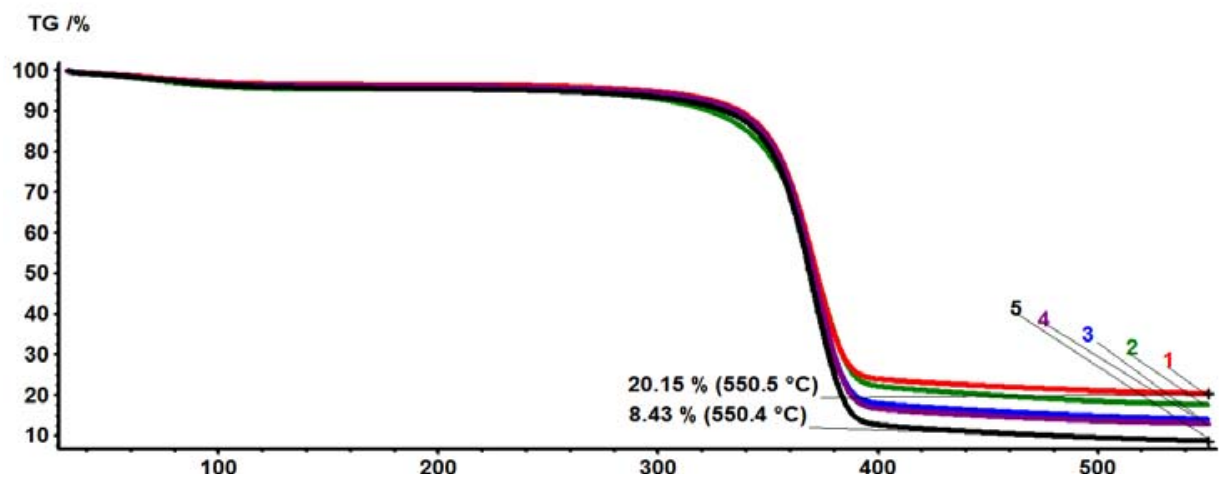

DTG $/(\% / m i n)$

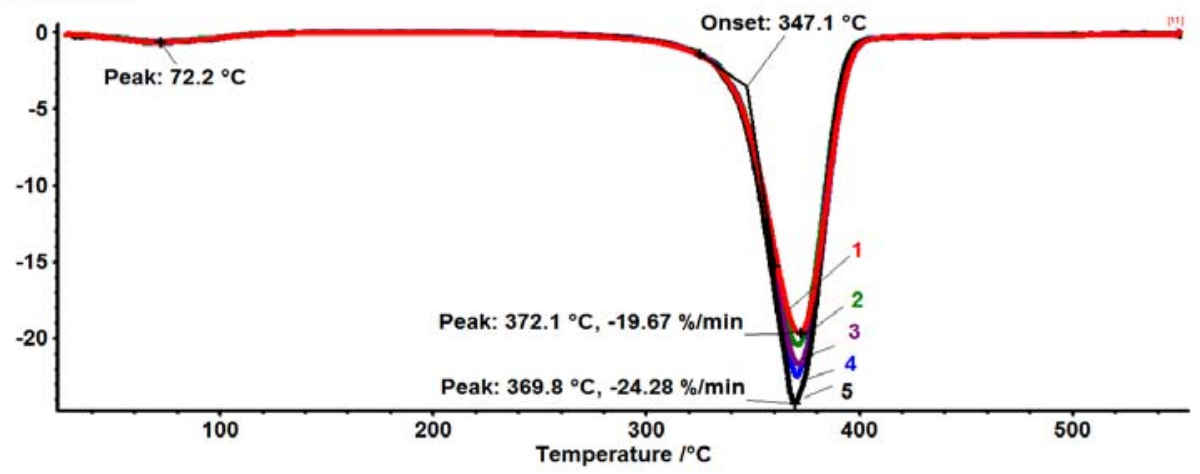

Fig. 4 - TG/DTG curves of: 1-usBSF2-15, 2-usBSF1-35, 3-usBSF2-35, 4-usBSF2-55, 5-BSF3-35 samples. 
Table 2

The main DTG temperature values and $-(\mathrm{d} \Delta \mathrm{m} / \mathrm{dt})$ at $370^{\circ} \mathrm{C}$ for the investigated samples ${ }^{*}$

\begin{tabular}{|c|c|c|c|c|c|c|}
\hline \multirow[b]{2}{*}{ Sample } & \multicolumn{3}{|c|}{ Without ultrasound } & \multicolumn{3}{|c|}{ With ultrasound } \\
\hline & $\begin{array}{l}\mathbf{T}_{\text {onset }} \\
/\left({ }^{\circ} \mathbf{C}\right) \\
\end{array}$ & $\begin{array}{l}\mathbf{T}_{\text {DTG }} \\
/\left({ }^{\circ} \mathbf{C}\right) \\
\end{array}$ & $\begin{array}{c}-(\mathrm{d} \Delta \mathrm{m} / \mathrm{dt})_{370}{ }^{0} \mathrm{C} \\
/(\% / \mathrm{min}) \\
\end{array}$ & $\begin{array}{l}\mathbf{T}_{\text {onset }} \\
/\left({ }^{\circ} \mathbf{C}\right) \\
\end{array}$ & $\begin{array}{l}\mathbf{T}_{\text {DTG }} \\
/\left({ }^{\circ} \mathbf{C}\right) \\
\end{array}$ & $\begin{array}{c}-(\mathrm{d} \Delta \mathrm{m} / \mathrm{dt})_{370}{ }^{\circ} \mathrm{C} \\
/(\% / \mathrm{min})\end{array}$ \\
\hline RWF & 341.6 & 373.0 & 17.60 & - & - & 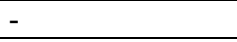 \\
\hline $\begin{array}{l}\text { BSF2-15/ } \\
\text { usBSF2-15 }\end{array}$ & 345.0 & 373.8 & 17.61 & 347.1 & 372.1 & 19.45 \\
\hline $\begin{array}{l}\text { BSF1-35/ } \\
\text { usBSF1-35 }\end{array}$ & 345.6 & 372.3 & 20.05 & 347.3 & 371.3 & 20.37 \\
\hline $\begin{array}{l}\text { BSF2-35/ } \\
\text { usBSF2-35 }\end{array}$ & 345.7 & 371.5 & 20.63 & 347.8 & 371.8 & 21.51 \\
\hline $\begin{array}{l}\text { BSF3-35/ } \\
\text { usBSF3-35 }\end{array}$ & 346.0 & 371.1 & 22.23 & 348.8 & 369.8 & 24.26 \\
\hline $\begin{array}{l}\text { BSF2-55/ } \\
\text { usBSF2-55 }\end{array}$ & 346.4 & 371.8 & 22.46 & 346.2 & 370.8 & 22.39 \\
\hline ATF & 335.3 & 370.0 & 15.80 & - & - & - \\
\hline
\end{tabular}

At the beginning of second mass-loss stage, the thermal degradation/pyrolysis of non-cellulosic components structure (especially pectin and hemicelluloses) take place which overlap and influence the cellulose decomposition/pyrolysis reactions. ${ }^{20}$ The lignin has been shown to degrade in wide temperature interval $\left(200-550^{\circ} \mathrm{C}\right)^{21}$ and due to the fact that the bio-treatment with pectinase does not affect the lignin content from the fabric, its influence on the thermal decomposition of the samples is not taken into consideration in this work. It is well known from literature that cellulose has a complex gradual degradation which involves two types of reactions: depolymerisation reaction with formation of levoglucosan that at higher temperature breaks-down to given low molecular-mass volatile compounds (ketones, aldehydes, furans and pyrans) and dehydration reaction with char formation. ${ }^{20-24}$ The presence of pectin and small amounts of metallic ions, like calcium pectate from network structure that bonds cuticle and primary wall, could influence the char quantity produced in cellulose degradation. ${ }^{20}$

Consequently, the efficacy of the bioscouring can be estimated from the recorded values of massloss $\left(\% \Delta \mathrm{m}_{2}\right)$ and $\%$ residual-mass (at $\left.550^{\circ} \mathrm{C}\right)$, these thermal parameters being in correlation with the remaining non-cellulosic and metallic ions content of the cotton-flax fabric samples.

The temperature values where the main decomposition step begins $\left(\mathrm{T}_{\text {onset }}\right)$, obtained from DTG curves, the maximum DTG peak temperature $\left(\mathrm{T}_{\mathrm{DTG}}\right)$ and the values of the derivative for $\mathrm{T}=370^{\circ} \mathrm{C}\left((\mathrm{d} \Delta \mathrm{m} / \mathrm{dt})_{370^{\circ} \mathrm{C}}\right)$ are given in Table 2 .

The $\mathrm{T}_{\text {onset }}$ value obtained from DTG curve for RWF is $\sim 342^{\circ} \mathrm{C}$ being close to the reported value in literature for cotton fabric $\left(\mathrm{T}_{\mathrm{DTG}} \sim 347^{\circ} \mathrm{C}\right) .{ }^{26}$ The $\mathrm{T}_{\text {onset }}$ value slightly increases for bioscoured samples ( $\mathrm{T}_{\text {onset BSCX-y }} \sim 345^{\circ} \mathrm{C}, \mathrm{T}_{\text {onset usBSCx-y }} \sim 347^{\circ} \mathrm{C}$ ) with the removal of non-cellulosic attendants from the fabric.

A more significant variation was observed in the height of the DTG peaks as can be seen from the Fig. 2, Fig. 3 and Fig. 4. The maximum of the DTG peaks $\left(\mathrm{T}_{\mathrm{DTG}}\right)$ corresponds to the inflection point from the TG curves and the values of the derivative indicating the maximum decomposition rate. The $\mathrm{T}_{\mathrm{DTG}}$ values decrease with $\sim 4^{\circ} \mathrm{C}$ from RWF to BSCx-y and usBSCx-y while the maximum mass loss rate increases from $18.00 \% / \mathrm{min}$. to $22.72 \% / \mathrm{min}$. and $24.27 \% / \mathrm{min}$. for BSF3-35/usBSF3-35. This variation is due to the enzymatic elimination of pectin from the samples, in accordance with the FT-IR results and also to $\mathrm{Ca}^{2+}$ ions elimination under the action of the complexing agent.

For a better evaluation of bioscouring efficacy the $-(\mathrm{d} \Delta \mathrm{m} / \mathrm{dt})$ values were determined at a fixed temperature $\left(370^{\circ} \mathrm{C}\right)$ for all samples. As expected based on FT-IR results, all bioscoured samples presented higher values comparing with RWF sample and the maximum values were obtained for usBSFx-y samples than for the BSFx-y. It should be noted that the $-(\mathrm{d} \Delta \mathrm{m} / \mathrm{dt})$ value of the usBSF2-55 sample is lower than that for usBSF3-35 even though the FT-IR results show that for a longer enzyme action time and sonication the pectin elimination was more advanced.

The mass-loss values $(\% \Delta \mathrm{m})$ for the recorded decomposition steps and \% residual - mass from the TG curves are presented in Table 3. 
Table 3

The $\%$ mass-loss and $\%$ residual- mass values from the TG curves of the investigated samples ${ }^{*}$

\begin{tabular}{|c|c|c|c|c|c|c|}
\hline \multirow[b]{2}{*}{ Sample } & \multicolumn{3}{|c|}{ Without ultrasound } & \multicolumn{3}{|c|}{ With ultrasound } \\
\hline & $\begin{array}{c}\left(\% \Delta \mathrm{m}_{1}\right) \\
\left(80-120^{\circ} \mathrm{C}\right) \\
\end{array}$ & $\begin{array}{c}\left(\% \Delta \mathrm{m}_{2}\right) \\
\left(260-400^{\circ} \mathrm{C}\right)\end{array}$ & $\begin{array}{c}\% \text { residual-mass } \\
\left(550^{\circ} \mathrm{C}\right)\end{array}$ & $\begin{array}{c}\left(\% \Delta \mathbf{m}_{1}\right) \\
\left(80-120^{\circ} \mathrm{C}\right)\end{array}$ & $\begin{array}{c}\left(\% \Delta \mathrm{m}_{2}\right) \\
\left(260-400^{\circ} \mathrm{C}\right) \\
\end{array}$ & $\begin{array}{c}\text { \% residual-mass } \\
\left(550^{\circ} \mathrm{C}\right)\end{array}$ \\
\hline RWF & $3.03 \pm 1.12$ & $68.15 \pm 1.13$ & $25.09 \pm 0.16$ & - & - & - \\
\hline $\begin{array}{l}\text { BSF2-15/ } \\
\text { usBSF2-15 }\end{array}$ & $3.04 \pm 1.48$ & $69.25 \pm 0.81$ & $23.45 \pm 1.05$ & $4.86 \pm 1.12$ & $73.27 \pm 1.35$ & $20.15 \pm 1.12$ \\
\hline $\begin{array}{l}\text { BSF1-35/ } \\
\text { usBSF1-35 }\end{array}$ & $4.27 \pm 1.14$ & $73.67 \pm 0.43$ & $19.19 \pm 0.98$ & $4.81 \pm 1.77$ & $76.09 \pm 0.90$ & $17.42 \pm 0.88$ \\
\hline $\begin{array}{l}\text { BSF2-35/ } \\
\text { usBSF2-35 }\end{array}$ & $3.57 \pm 1.32$ & $76.83 \pm 0.54$ & $15.67 \pm 0.81$ & $4.48 \pm 1.42$ & $78.32 \pm 0.97$ & $13.89 \pm 1.87$ \\
\hline $\begin{array}{l}\text { BSF3-35/ } \\
\text { usBSF3-35 }\end{array}$ & $4.53 \pm 0.64$ & $77.07 \pm 0.89$ & $15.06 \pm 0.65$ & $4.52 \pm 0.98$ & $83.31 \pm 1.22$ & $8.43 \pm 1.65$ \\
\hline $\begin{array}{l}\text { BSF2-55/ } \\
\text { usBSF2-55 }\end{array}$ & $4.74 \pm 1.22$ & $78.86 \pm 1.44$ & $12.78 \pm 1.12$ & $4.04 \pm 1.16$ & $78.94 \pm 0.87$ & $13.71 \pm 1.42$ \\
\hline ATF & $4.10 \pm 1.11$ & $76.40 \pm 0.55$ & $14.77 \pm 0.88$ & - & - & - \\
\hline
\end{tabular}

* Values are the average of three determinations

It can be seen that all samples have approximately the same humidity $\left(\% \Delta \mathrm{m}_{1}=3.03-\right.$ $4.86 \%$ ). In the case of RWF sample, the lowest value for the $\% \Delta \mathrm{m}_{2}$ and the highest value for $\%$ residual-mass at $550^{\circ} \mathrm{C}$ were recorded. This behaviour is due to the high content of noncellulosic components (pectin, hemicelluloses and waxes) which decompose at lower temperatures $\left(\sim 337.9^{\circ} \mathrm{C}\right)$ than cellulose. A higher content of pectin lead to a higher amount of char formation. The char could limit the rate of cellulose decomposition by delaying the volatility rate of the gases produced. ${ }^{32}$ Hence, the removal of pectin from the surface of cotton and flax fibres in bioscouring treatment caused a greater rate of cellulose mass loss (see Table 2) and led to the increasing of $\% \Delta \mathrm{m}_{2}$ and to diminishing of $\%$ residual-mass. For BSFx-y samples the increase of the enzyme concentration in the treatment bath from $1 \%$ o.w.f. to $2 \%$ o.w.f. determined the increase of $\% \Delta \mathrm{m}_{2}$ values with $\sim 3 \%$ and the decrease in $\%$ residual-mass by $\sim 4 \%$. A subsequent increase in enzyme concentration to $3 \%$ o.w.f. did not significantly affect the mass-loss values. Similarly, the increase of enzyme action time from $15 \mathrm{~min}$. to $35 \mathrm{~min}$. led to a larger amount of pectin removal than the increase from $35 \mathrm{~min}$. to $55 \mathrm{~min}$. These results are in good agreement with the previously obtained data related to the influence of the bioscouring conditions on the hydrophilic properties of the cotton fabric. ${ }^{16}$ Compared to the BSFx-y samples, the usBSFx-y showed, for the same enzyme conditions, higher values for $\% \Delta \mathrm{m}_{2}$ and lower values for $\%$ residual-mass $\left(550^{\circ} \mathrm{C}\right)$, respectively. This demonstrates the efficacy of the ultrasonication for a larger amount of pectin removal even at a short action time of enzyme (15 min.). These results are in line with those obtained from the FT-IR analysis and data from Table 2. In the ultrasonication conditions the powerful agitation of the liquid border layer caused by cavitation substantively improve the transport of bulky enzyme molecules toward the fabric surface and increase the overall reaction rate. For the ATF sample, even if the FT-IR results indicate advanced pectin elimination, the thermal stability is lower than for the raw woven fabric and all ecofriendly treated samples $\left(\mathrm{T}_{\text {onsetATF }} \sim 335^{\circ} \mathrm{C}\right)$. This can be explained by the fact that some of the hydrogen bonds between the cellulose polymers chains were degraded by $\mathrm{NaOH}$, reducing the crystallinity, as it was noticed by the "amorphous" and "crystallinity" bands modifications. Besides, the modification in cellulose molecular chains with the formation of low molecular weight fragments it can occur which accelerate the thermal degradation process. On the other hand, any remaining $\mathrm{Na}^{+}$ metal ions may be present as $\left(-\mathrm{O}^{-} \mathrm{Na}^{+}\right)$groups and can depress the degradation rate $\left(-(\mathrm{d} \Delta \mathrm{m} / \mathrm{dt})_{370}{ }^{0} \mathrm{C}=\right.$ $15.80 \% / \mathrm{min}$.) of cellulosic chains influencing the $\left(\% \Delta \mathrm{m}_{2}\right)$ and $\%$ residual-mass values. The obtained TG/DTG results for usBSF2-55 sample can be also explained by changes in the cellulose crystallinity noticed in the intensity bands located at $896 \mathrm{~cm}^{-1}$ and $1428 \mathrm{~cm}^{-1}$. By prolonging the time of ultrasonication, a local overheating may appear and affect the structure of the cellulose chains. Thus, a change in the cellulose decomposition mechanism takes place, which alters the decomposition rate $\left(-(\mathrm{d} \Delta \mathrm{m} / \mathrm{dt}) 370{ }_{\mathrm{C}}{ }^{0}=22.39 \% / \mathrm{min}\right.$.) and the $\%$ mass-loss $\left(\% \Delta \mathrm{m}_{2}=78.94\right)$. 


\section{CONCLUSIONS}

The influence of the ultrasonication and enzyme conditions on the pectin elimination in eco-friendly scouring treatment of a cotton-flax fabric $(40 \%$ flax- $60 \%$ cotton) was investigated by FT-IR and TG/DTG thermal analysis and the obtained results were in a good agreement (except the usBSF2-55 sample). The data showed an increasing of $\mathrm{T}_{\text {onset }}$ of the main decomposition step for the bioscoured samples compared to row fabric due to the noncellulosic components elimination. A larger amount of pectin eliminated led to increases of the decomposition rate and mass loss values in the main degradation stage of cellulose and to the diminishing of $\%$ residual-mass. The presence of metallic ions can depress the thermal degradation of cellulosic chains affecting the degradation rate $\left(-(\mathrm{d} \Delta \mathrm{m} / \mathrm{dt})\right.$, mass-loss $\left(\% \Delta \mathrm{m}_{2}\right)$ and $\%$ residualmass values. The influence of the ultrasonication on pectin elimination can be observed even at a short action time of enzyme (15 min.) on the textile substrate, but a prolonged treatment can destroy the macromolecular and crystallinity structure of the cellulose chains, altering the values of TG/DTG thermal parameters. By correlating with other specific analyses, the TG/DTG can be used for quantifying the efficiency of the fabrics bioscouring process.

Acknowledgements. This work was supported by a grant of the Roumanian National Authority for Scientific Research and Innovation, CNCS - UEFISCDI, project number PN-II-RUTE-2014-4-1370.

\section{REFERENCES}

1. P. J. Wakelyn, N. R. Bertoniere, A. D. French, D. P. Thibodeaux, B. A. Triplett, M. A. Rousselle, W. R. Goynes, J. V. Edwards Jr., L. Hunter, D. D. McAlister and G. R. Gamble, "Cotton Fibers", in "Handbook of Fiber Chemistry", $3^{\text {th }}$ edition, Taylor \& Francis Group, New York, 2007, p. 523.

2. M. Dochia, M. D. Stanescu and C. Constantin, Fibres Text. East. Eur., 2013, 21, 22-25.

3. S. Perincek and K. Duran, J. Clean. Prod., 2016, 135, 1179-1188.

4. C. Lin and Y. L. Hsieh, Text. Res. J., 2001, 71, 425-434.

5. Q. Wang, X. Fan, W. Gao and J. Chen, Carbohyd Res., 2006, 341, 2170-2175.
6. G. R. Gamble, J. Agr. Food Chem., 2003, 51, 7995-7998.

7. E. S. Abdel-Halim, H. M. Fahmy and M. G. Fouda Moustafa, Carbohyd. Polym., 2008, 74, 707-711.

8. Q. Wang, X. Fan, Z. Hua, W. Gao and J. Chen, Biocatal. Biotransfor., 2007, 25, 8-15.

9. C. Vigneswaran, M. Ananthasubramanian and N. Anubumani, Indian J. Fibre Text., 2013, 38, 44-56.

10. B. L. Ridley, M. A. O'Neill and D. Mohnen, Phytochemistry, 2001, 57(6), 929-967.

11. K. Sawada, S. Tokino, M. Ueda and X. Wang, J. Soc. Dyers Colour., 2003, 114, 333-336.

12. M. D. Stanescu, M. Fogorasi, S. Mihuta, M. Dochia and V. I. Lozinsky, Rev. Chim., 2009, 60, 59-62.

13. M. Calafell and P Garriga, Enzyme Microb. Technol., 2004, 34, 326-331.

14. R. Araujo, M. Casal and A. Cavaco-Paolo, Biocatal. Biotransfor., 2008, 26, 332-349.

15. C. Chung, M. Lee and E. K. Choe, Carbohyd. Polym., 2004, 58, 417-420.

16. M. D. Stanescu, M. Dochia, D. Radu and C. Sirghie, Fibres Text. East. Eur., 2010, 18, 109-11.

17. S. Kalantzi, D. Mamma, P. Christakopoulos and D. Kekos, Bioresour. Technol., 2008, 99, 8185-8192.

18. M. D. Stanescu, M. Fogorasi, M. S. Bucur, M. Pustianu and M. Dochia, Sci. Bull. B Chem. Mater. Sci. UPB, 2010, 72, 21-28.

19. S Alix, E. Philippe, A. Bessadok, L. Lebrun, C. Morvan and S. Marais, Bioresour. Technol., 2009, 100, 47244729.

20. I. Cabrales and N. Abidi, J. Therm. Anal. Calorim., 2010, 102, 485-491.

21. E. Corradini, E. M. Teixeira, P. D. Paladin, J. A. Agnelli, O.R.R.F. Silva and L. H. C., J. Therm. Anal. Calorim., 2009, 97, 415-419.

22. A. L. F. S. d'Almeida, D. W. Barreto, V. Calado and J. R. M. d'Almeida, J. Therm. Anal. Calorim., 2008, 91, 405-408.

23. A. A. Saafan and A. M. Habib, J. Therm. Anal. Calorim., 1987, 32, 1511-1519.

24. C. M. Tian, Z. H. Shi, H. Y. Zhang, J. Z. Xu, J. R. Shi and H. Z. Guo, J. Therm. Anal. Calorim., 1999, 55, 93-98.

25. L. Zhang, J. He and S. Y. Wanh, J. Therm. Anal. Calorim., 2009, 2, 653-659.

26. M. Dochia, D. Chambre, S. Gavrilas and C. Moisa, $J$. Therm. Anal. Calorim., 2018, 132, 1489-1498.

27. L.Bílková, Polym. Degrad. Stab., 2012, 97, 35-39.

28. Z. Kovačević, S. Bischof Vukušić and M. Zimniewska, Text. Res. J., 2012, 82, 1786-1798.

29. K. Subramanian, P. Senthil Kumar, P. Jeyapal and N. Venkatesh, Eur. Polym. J., 2005, 41, 853-861.

30. J. Čopiková, A. Synytsya, M. Černá, J. Kaasová and M. Novotá, Czech J. Food Sci, 2001, 19, 51-56.

31. D. Ciolacu, F. Ciolacu and V. I. Popa, Cellul. Chem. Technol., 2011, 45, 13-21.

32. S. Ouajai and R. A. Shanks, Polym. Degrad. Stab., 2005, $89,327-335$. 